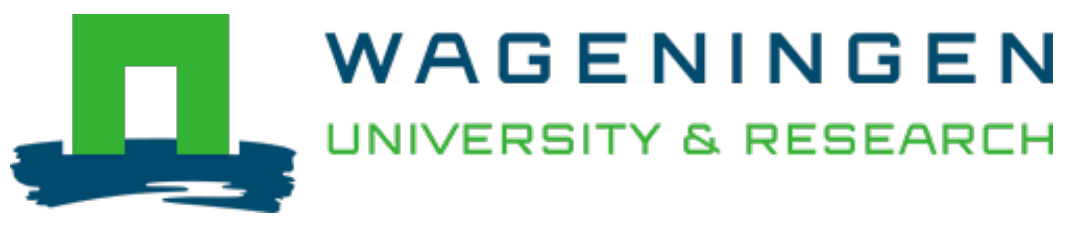

\title{
Effect of sterilization and storage on a model meat analogue pet food
}

Animal Feed Science and Technology

Wehrmaker, Ariane Maike; Bosch, Guido; Goot, Atze Jan

https://doi.org/10.1016/j.anifeedsci.2020.114737

This publication is made publicly available in the institutional repository of Wageningen University and Research, under the terms of article $25 \mathrm{fa}$ of the Dutch Copyright Act, also known as the Amendment Taverne. This has been done with explicit consent by the author.

Article $25 \mathrm{fa}$ states that the author of a short scientific work funded either wholly or partially by Dutch public funds is entitled to make that work publicly available for no consideration following a reasonable period of time after the work was first published, provided that clear reference is made to the source of the first publication of the work.

This publication is distributed under The Association of Universities in the Netherlands (VSNU) 'Article $25 \mathrm{fa}$ implementation' project. In this project research outputs of researchers employed by Dutch Universities that comply with the legal requirements of Article $25 \mathrm{fa}$ of the Dutch Copyright Act are distributed online and free of cost or other barriers in institutional repositories. Research outputs are distributed six months after their first online publication in the original published version and with proper attribution to the source of the original publication.

You are permitted to download and use the publication for personal purposes. All rights remain with the author(s) and / or copyright owner(s) of this work. Any use of the publication or parts of it other than authorised under article $25 \mathrm{fa}$ of the Dutch Copyright act is prohibited. Wageningen University \& Research and the author(s) of this publication shall not be held responsible or liable for any damages resulting from your (re)use of this publication.

For questions regarding the public availability of this publication please contact openscience.library@wur.nl 


\title{
Effect of sterilization and storage on a model meat analogue pet food
}

\author{
Ariane Maike Wehrmaker ${ }^{\mathrm{a}, *}$, Guido Bosch ${ }^{\mathrm{b}}$, Atze Jan van $\operatorname{der}_{\text {Goot }}{ }^{\mathrm{c}}$ \\ ${ }^{a}$ saturn petcare Gmbh, Senator-Mester-Straße 1, 28197, Bremen, Germany \\ ${ }^{\mathrm{b}}$ Animal Nutrition Group, Wageningen University, PO Box 338, $6700 \mathrm{AH}$, Wageningen, the Netherlands \\ ${ }^{\mathrm{c}}$ Laboratory of Food Process Engineering, Wageningen University, PO Box 17, 6700 AA, Wageningen, the Netherlands
}

\section{A R T I C L E I N F O}

\section{Keywords:}

Pet food technology

Novel protein

Vegan

Plant-based

Sterilization

Texture profile analysis

\begin{abstract}
A B S T R A C T
Recently, it was demonstrated that it is possible to create highly fibrous meat analogues, using simple shear structuring. We investigated how the model meat analogue responds to sterilization and storage in media (water, jelly, or gravy) with pet food and beef chunks as reference. Chunks were analysed before and after sterilization, and after storage for textural properties and proximate composition. The fibrous appearance of the model meat analogue was retained after sterilization and storage. Moisture uptake of the model meat analogue was about twice the amount of that in pet food, resulting in textural properties approaching pet food after sterilization. Proximate composition and texture of the model meat analogue remained stable during storage, except for in gravy, which was probably caused by the salt content in the gravy. Due to the fibrousness and pet food-like texture after sterilization, the model meat analogue can be considered promising for the development of plant-based pet foods.
\end{abstract}

\section{Introduction}

Increasing awareness of animal welfare and environmental sustainability drives a shift in human diets towards more plant-based and fuels the development of meat analogues for these diets. As owners tend to humanize their pets (Fox and Gee, 2017), many trends in human nutrition find their way into pet nutrition. Though vegan and vegetarian pet foods are still a niche market, it can be expected that meat analogue-like products will find their way into pet foods as well (Okin, 2017; Su et al., 2018). An additional argument to look for plant alternatives is that animal derived products like meat by-products or meat, might become less available for the pet food industry in the future, as these products can be used for human food, pharmaceuticals, or cosmetics (Toldrá et al., 2016). It is even possible that meat by-products will become scarce because of introduction of breakthrough technology such as in vitro meat production (Stephens et al., 2018). It is generally accepted that consumers prefer a resemblance to meat when choosing meat analogues (Hoek et al., 2011). Likewise, pet owners increasingly prefer pet food with a high meat content (Swanson et al., 2013), which relates to the carnivorous background of dogs and cats (Hendriks and Bosch, 2018). Meat analogue with meat-like fibres like the couette cell meat analogue (CCMA) (Krintiras et al., 2014) is predestined for use as sustainable pet food. It is unclear, however, how pet food

\footnotetext{
Abbreviations: CCMA, couette cell meat analogue; N, nitrogen; SPI, soy protein isolate; TPA, texture profile analysis; WHC, water holding capacity.

* Corresponding author.

E-mail addresses: awehrmaker@saturn-petcare.de (A.M. Wehrmaker), guido.bosch@wur.nl (G. Bosch), atzejan.vandergoot@wur.nl (A.J. van der Goot).
} 
processing, especially sterilization, affects the properties of meat analogues. Rigorous data are lacking regarding how to ensure specific pet food characteristics.

Canned pet foods are mainly made out of animal-derived ingredients, plus the necessary vitamins and minerals to fulfil the nutrient profile of the target species. The recipe is adapted to either resemble a meat loaf type and/or a ragout type, the latter being meat or meat analogue chunks with or without vegetables. The chunks and vegetables are placed in different aqueous media like jelly and gravy made from hydrocolloids such as locust bean gum and xanthan gum for jelly, and xanthan and guar gum for gravy (Sworn, 2009). Before sterilization, canned pet food undergoes comminution and mixing of the fresh, dried or frozen ingredients to a homogenous paste. Depending on the final product, the paste is then simmered and cut into chunks or directly filled into cans, trays, or pouches, with or without the addition of a medium. To ensure shelf-life of a minimum of 24 months, pet food needs to be heated to $121.1^{\circ} \mathrm{C}$ for at least $3 \mathrm{~min}$ (sterilization). When pet food is sterilized in a medium, the physical properties of the product might change due to, for example, water-uptake or -release by the chunks as well as hydrolysis reactions of the animal proteins (Chou and Morr, 1979; Kinsella, 1979). These changes can continue during storage. The physical properties like hardness of the final pet food are important for acceptance by the pet and, as such, are an essential parameter when developing new products.

Meat analogues might be susceptible to the high temperatures typically used in pet food sterilization. Above $80{ }^{\circ} \mathrm{C}$, soy proteins start to denature and around $140{ }^{\circ} \mathrm{C}$, degradation begins (Kinsella, 1979). Denaturation of proteins, which is dependent on water content, impact the protein's functionality (De Graaf, 2000). Thermal processing can impact the structural integrity, which is important in meat analogues with fibrous structures like CCMA. Berghout et al. (2015) showed that particles of a soy protein isolate (SPI) dispersion started to disintegrate upon longer heating time at $80^{\circ} \mathrm{C}$ for $8 \mathrm{~h}$. Proteins in CCMA are denatured, but the exact state of the proteins after shearing is not known yet, hence it is difficult to envisage possible changes of the CCMA through sterilization.

In this exploratory study, we evaluated how the properties of fibrous plant-based chunks change during processing conditions typically used to produce canned pet foods. Since changes in structure of the CCMA product can be expected as well, it is interesting to investigate the susceptibility of the product to high temperatures as commonly applied in the manufacturing of canned pet foods. The jelly and gravy types of media have hydrophilic properties and form networks varying from firm to flowing gels, which might impact the response of a CCMA to sterilization. We hypothesized that upon sterilization the CCMA could fall apart and components of the CCMA solubilize when sterilized in water, but will stay intact when sterilized in jelly (firm gel) and gravy (flowing gel). Jelly and gravy have a greater viscosity, which will hinder CCMA to swell and fall apart. In addition, the binders present in jelly and gravy have hydrophilic properties, therefore preventing the water to enter the chunks, which will reduce swelling as well.

To evaluate physicochemical properties of CCMA as a pet food model under sterilization and storage in these types of media, chunks of the CCMA were compared with beef chunks and commercially available pet food of the type with chunks. Measurements of the chunks included proximate composition, texture, adhesion, and for the media viscosity and pH were measured. The measurements were conducted before sterilization/filling, shortly after sterilization (1 day for pet food and beef chunks, 2 days for CCMA chunks) and during storage at 7 and 28 days after sterilization.

\section{Material and methods}

\subsection{Food composition and production}

CCMA chunks were composed out of $690 \mathrm{~g} / \mathrm{kg}$ water, $230 \mathrm{~g} / \mathrm{kg}$ SPI (Supro® EX 37 IP, Solae, St. Louis, USA), $70 \mathrm{~g} / \mathrm{kg}$ vital wheat gluten (VITEN ${ }^{\circledR}$, Roquette, Lestrem, France) and $10 \mathrm{~g} / \mathrm{kg}$ salt and were produced according to previous procedures (Krintiras et al., 2016). The raw material was inserted into the couette device where it was sheared between two cylinders - one stationary and one rotating - at $120^{\circ} \mathrm{C}$ for $30 \mathrm{~min}$ with $30 \mathrm{rpm}$. The pet food chunks were composed out of $522 \mathrm{~g} / \mathrm{kg}$ poultry (mechanically deboned turkey, and chicken), $289 \mathrm{~g} / \mathrm{kg}$ meat by-products (liver, spleen), $78 \mathrm{~g} / \mathrm{kg}$ water, $33 \mathrm{~g} / \mathrm{kg}$ animal plasma, $23 \mathrm{~g} / \mathrm{kg}$ animal by-product meal, $20 \mathrm{~g} / \mathrm{kg}$ whole grain wheat flour (type 1050), $15 \mathrm{~g} / \mathrm{kg}$ vitamins,minerals and amino acids, $7 \mathrm{~g} / \mathrm{kg}$ sodium tripolyphosphate, 1 $\mathrm{g} / \mathrm{kg}$ salt, and $0.2 \mathrm{~g} / \mathrm{kg}$ canola oil. For the pet food chunks, the frozen blocks of poultry and meat by-products were broken, ground to 2 $\mathrm{mm}$ and mixed with the water and dry ingredients. The emulsion was spread into strips on a solid belt of a steam tunnel where it was cooked $\left(81^{\circ} \mathrm{C}, 70 \mathrm{~s}\right)$ and strips were cut into chunks after passing a stencil $(10 \times 10 \times 20 \mathrm{~mm})$. The beef chunks were made from strips of low fat $\left(<80 \mathrm{~g} / \mathrm{kg}\right.$ ) silverside, topside, and leg of Irish bulls. The CCMA product and beef, initially stored at $-18{ }^{\circ} \mathrm{C}$ were thawed, heated to $40{ }^{\circ} \mathrm{C}$ and cut into chunks of approximately $10 \times 10 \times 20 \mathrm{~mm}$. In this publication, the wording CCMA, pet food, and beef is used interchangeably with CCMA chunks, pet food chunks, and beef chunks, respectively.

The media used were tap water (control), jelly, and gravy. The binders used in the jelly were carrageenan, xanthan gum and locust bean gum. These gelling agents immobilise water through cross-linking of the polymer chains. Formulated composition of jelly was $985 \mathrm{~g} / \mathrm{kg}$ moisture, $11 \mathrm{~g} / \mathrm{kg}$ crude protein, $0.2 \mathrm{~g} / \mathrm{kg}$ crude fat, $4.7 \mathrm{~g} / \mathrm{kg}$ crude ash (Bestmix, Adifo, Maldegem, Belgium). The gravy contained xanthan gum, and guar gum as binders, and salt. The formulated composition was $982 \mathrm{~g} / \mathrm{kg}$ moisture, $77 \mathrm{~g} / \mathrm{kg}$ crude protein, $0.6 \mathrm{~g} / \mathrm{kg}$ crude fat, and $1.8 \mathrm{~g} / \mathrm{kg}$ crude ash (Bestmix, Adifo, Maldegem, Belgium).

For each chunk type (CCMA, pet food, beef), 24 cans (400 g, DWI, Ardagh, Deventer, the Netherlands; Softlid, Ardagh, Erftstadt, Germany) were made with eight cans for each of the three media types. Each can was filled with approximately $180 \mathrm{~g}$ of chunks and the remainder was filled with the medium. A headspace was left for pressure control. The exact weights of chunks and media were noted.

\subsection{Sterilization and storage}

The cans were sterilized using a continuous flow sterilization device (Hydromatic, Stork, Bad Oeynhausen, Germany) at $124.5{ }^{\circ} \mathrm{C}$ 
and 1.28 bar for $36.6 \mathrm{~min}$. Two wireless data loggers for each chunk type were used to monitor the pressure of the sterilization system (TSPro, Ellab, Hilleroed, Denmark) and three loggers for each chunk and medium combination were used to monitor the products' temperature (TSPro Mini Temperature, Ellab, Hilleroed, Denmark). Sterilization was considered successful when F-values were sufficiently high to ensure sterility and when F-values were in a similar range for each medium. F-values were analysed using validation software (Valsuite Plus, Ellab, Hilleroed, Denmark).

F-values vary according to the heat transfer of the chunk and medium used. F-values were above 3 and in a similar range for each chunk and medium combination (average and standard deviation: CCMA x water $64 \pm 1.2$, CCMA x jelly $48 \pm 1$, CCMA x gravy $24 \pm$ 0.4 ; beef $x$ water $52 \pm 0.4$, beef x jelly $43.6 \pm 1.5$, beef $x$ gravy $21 \pm 2.0$; pet food $x$ water $71 \pm 0.7$, pet food x jelly $47.3 \pm 0.6$, pet food $x$ gravy $17 \pm 1.0$ ). Thus, sterility of products was ensured. The cans were kept at $21^{\circ} \mathrm{C}$ in a temperature controlled room for 1 day (pet food and beef) or 2 days (CCMA) after sterilization and for 7 or 28 days of storage.

\subsection{Proximate analyses}

Chunks were separated from the medium by emptying the can on a stainless steel sieve with a $2 \mathrm{~mm}$ mesh and a set time of $2 \mathrm{~min}$. In addition, any remaining jelly was manually removed with a stainless steel spatula. Nitrogen (N) was determined using the Kjeldahl method (method 2001.12, AOAC, 2005). Moisture was determined by drying the samples to a constant weight at $103{ }^{\circ} \mathrm{C}(\mathrm{method}$ 934.01, AOAC, 2005), after heating with hydrochloric acid crude oils and fats were extracted (method 954.02, AOAC, 2005), crude ash was determined by combusting at $550^{\circ} \mathrm{C}$ (method 942.05, AOAC, 2005). Each sample was analysed in duplicate and average values were presented.

\subsection{Texture profile analysis}

Chunks were separated from the medium by emptying the can on a stainless steel sieve with a $1-2 \mathrm{~mm}$ mesh and a set time of $1 \mathrm{~min}$. The TPA of the isolated chunks was performed with a texture analyser (Winopal TA.hd.plus, Winopal, Elze, Germany) having a maximum force of $50 \mathrm{~kg}, 80 \%$ strain (Bourne, 1975; Brady and Hunecke, 1985) and an equal speed to compression and withdrawal phases of $0.8 \mathrm{~mm} / \mathrm{sec}$ (Bourne, 1968). A round aluminium compression plate with $75 \mathrm{~mm}$ diameter (P/75, Winopal, Elze, Germany) was used. For CCMA and beef chunks, the force was applied parallel to the fibres (de Huidobro et al., 2005). For pet food chunks, force was applied perpendicular to their position in the steam tunnel. For each time point (i.e. before and after sterilization, 7 and 28 days of storage), one can per treatment was randomly selected for analysis of ten chunks. Average values as well as standard errors based on the technical replicates were calculated.

TPA parameters hardness, cohesiveness, springiness (former elasticity) and chewiness were calculated according to (Szczesniak, 1963) using Exponent 6.1.10.0 (Stable Micro Systems Ltd., Godalming, United Kingdom) TPA parameter resilience was calculated according to the macro in Exponent 6.1.10.0 (Stable Micro Systems Ltd., Godalming, United Kingdom) as Area 2:3 / Area 1:2.

For accurate determination of TPA, chunks with a uniform size were selected (Than et al., 2019). Couette, pet food, and beef chunks differed in height after sterilization. To only measure chunks with uniform height, outliers differing more than $+/$ - twice the standard deviation in height were excluded from the calculations. Of the total 270 TPA measurements after sterilization, there were 7 outliers.

\subsection{Adhesion}

Chunks were separated from the medium as described for the TPA after which adhesion was measured with the texture analyser equipped with a stainless ball (SMSP/1S, Winopal, Elze, Germany). The settings used were a force of $5 \mathrm{~kg}$, a compression speed of 0.5 $\mathrm{mm} / \mathrm{s}$, a withdrawal speed of $10 \mathrm{~mm} / \mathrm{s}$, and a holding time of $10 \mathrm{~s}$ with a pressure of $250 \mathrm{~g}$. For each time point, one can per treatment was randomly selected for analysis of ten chunks. Peak positive force ( $\mathrm{g}$ ) was recorded as value for adhesion. The data were analysed using the software Exponent 6.1.10.0 (Stable Micro Systems Ltd., Godalming, United Kingdom). Average values as well as standard errors based on the technical replicates were calculated and presented.

\subsection{Viscosity and $\mathrm{pH}$}

The medium was separated from the chunks by emptying the can on a stainless steel sieve with a $1-2 \mathrm{~mm}$ mesh and a set time of 1 min. Viscosity of the collected medium was measured with a viscometer (Brookfield model DV-2+, AMETEK, Lorch, Germany) spindle RV3 and $50 \mathrm{rpm}$. The $\mathrm{pH}$ of the media was determined with a pH-meter (testo $206 \mathrm{pH}-2$, Testo, Lenzkirch, Germany). All measurements were taken in a temperature controlled room $\left(21^{\circ} \mathrm{C}\right)$ and the temperature of the medium was recorded. For each time point, one can per treatment was randomly selected for one analysis of media.

\section{Results}

Visual inspection showed that after sterilization and 28 days of storage, CCMA chunks remained visible as separate chunks, which were swollen (Fig. 1). This effect was independent of the type of medium used. In all media, fibres were visible still but most pronounced in the gravy product. 

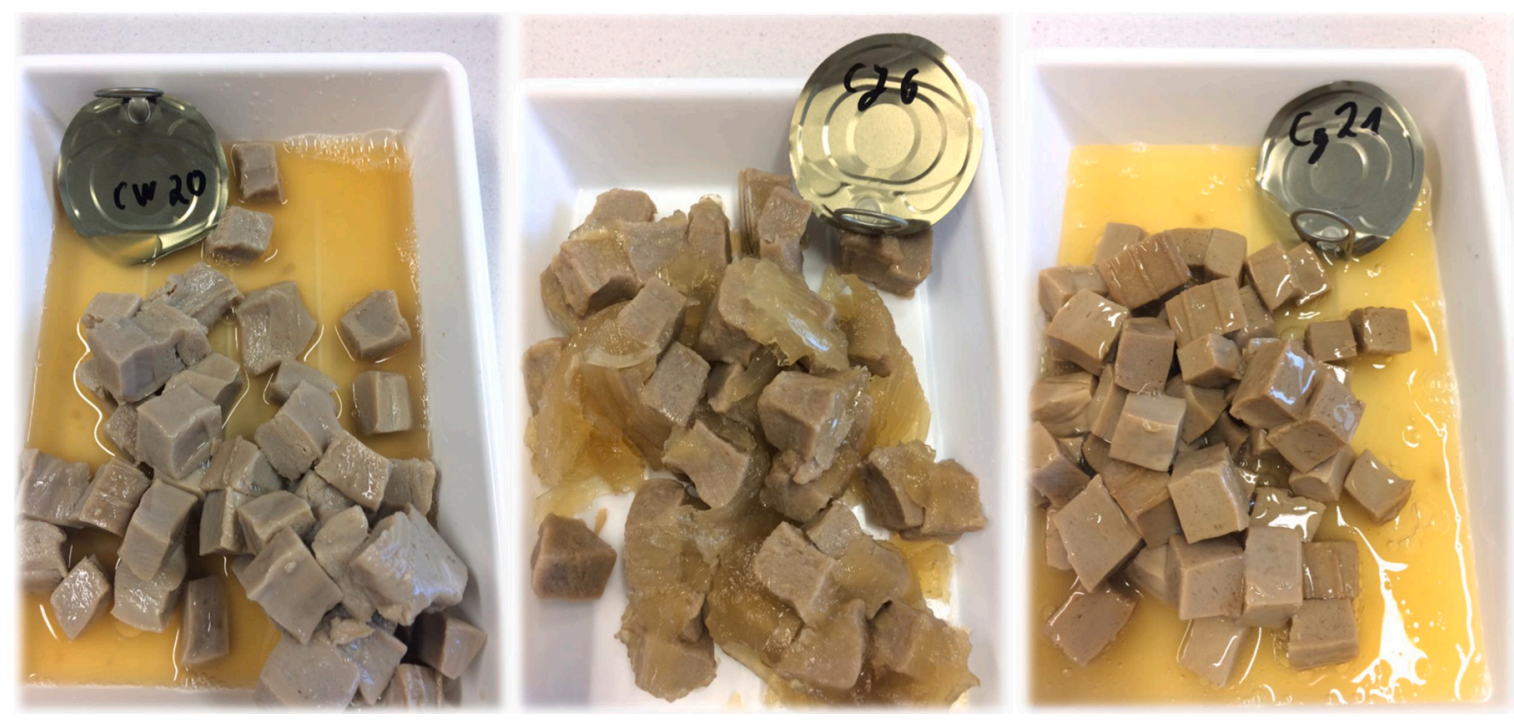

Fig. 1. CCMA chunks in water, jelly, and gravy (left to right) at day 28.

\subsection{Effect of sterilization on proximate composition of chunks}

Sterilization affected the exact chemical composition of the chucks. The changes in $\mathrm{N}$, fat, and ash depended on the type of medium used. Uptake of moisture was observed for CCMA and pet food chunks whereas beef chunks lost moisture (Fig. 2A). For CCMA, the total amount of moisture in chunks per can increased from 129 to $211 \mathrm{~g}$ when chunks were sterilized in water (uptake of $82 \mathrm{~g}$ ). In case of jelly, the water uptake was $57 \mathrm{~g}$ and in gravy, the uptake was $48 \mathrm{~g}$. Furthermore, the CCMA chunks lost more $\mathrm{N}$ when sterilized in jelly ( $1 \mathrm{~g}$ ) than in gravy or water (Fig. 2B). Also pet food chunks lost $\mathrm{N}$ when sterilized in water. Fat remained stable during sterilization of CCMA chunks, whereas some fat loss was observed for pet food chunks in gravy (2 g) and jelly (1 g). All chunks lost ash during sterilization, which was about $1 \mathrm{~g}$ for CCMA chunks and $2 \mathrm{~g}$ for pet food and beef chunks (Fig. 2D).

\subsection{Effect of sterilization on textural properties of chunks}

Sterilization affected textural properties of chunks. It was demonstrated that CCMA chunks had similar properties as pet food chunks after sterilization (Table 2), despite clear differences before sterilization. Hardness of CCMA chunks decreased from 35 to 8 (gravy), 4 (water) and $3 \mathrm{~kg}$ (jelly) after sterilization. Springiness of CCMA chunks decreased by 43 (water), 21 (gravy) and $36 \%$ (jelly), also approaching springiness of pet food chunks which increased by 14 (water), 13 (gravy), and $9 \%$ (jelly) after sterilization. Cohesiveness of CCMA chunks after sterilization approached pet food values by decreasing by 25 (water), 21 (gravy), and $26 \%$ (jelly). The approach to pet food values after sterilization is also true for chewiness of CCMA chunks, which decreased by 170 (gravy) to $186 \mathrm{~N}$ (jelly). Resilience of CCMA chunks decreased after sterilization by 0.08 (water) to 0.07 (gravy, jelly) to values similar to pet food.

\subsection{Effect of storage on proximate composition of chunks}

During storage, proximate composition remained stable. Thus, total amount of moisture in CCMA chunks per can remained stable. However, total moisture in CCMA chunks at day 7 had increased by $26 \mathrm{~g}$ (jelly) and $4 \mathrm{~g}$ (gravy) (Fig. 3A). Total fat in pet food chunks at day 7 had increased by 0.3 (water) to $2 \mathrm{~g}$ (gravy) (Fig. 3C). Total fat in pet food chunks per can at day 28 had decreased again by 0.1 (water) to $0.9 \mathrm{~g}$ (jelly). Total amount of ash in CCMA chunks per can remained stable except for the products with gravy. Here, a lower value was observed after 7 days. (Fig. 3D). Total amount of ash in pet food chunks per can remained stable. Total ash in pet food chunks at day 7 had decreased by 0.1 (water) to $0.06 \mathrm{~g}$ (jelly), at day 28 it had increased again by 0.3 (water) to $0.4 \mathrm{~g}$ (gravy).

\subsection{Effect of storage on textural properties of chunks}

During storage, textural properties remained stable (Fig. 4). However, for CCMA sterilized in gravy, greater values for hardness, springiness, cohesiveness, and chewiness were noted.

\section{Discussion}

There is growing interest in meat analogues and new and improved products like the CCMA with fibrous texture are being developed. There is also an interest in applying those types of products in canned pet foods. However, canned pet food production 

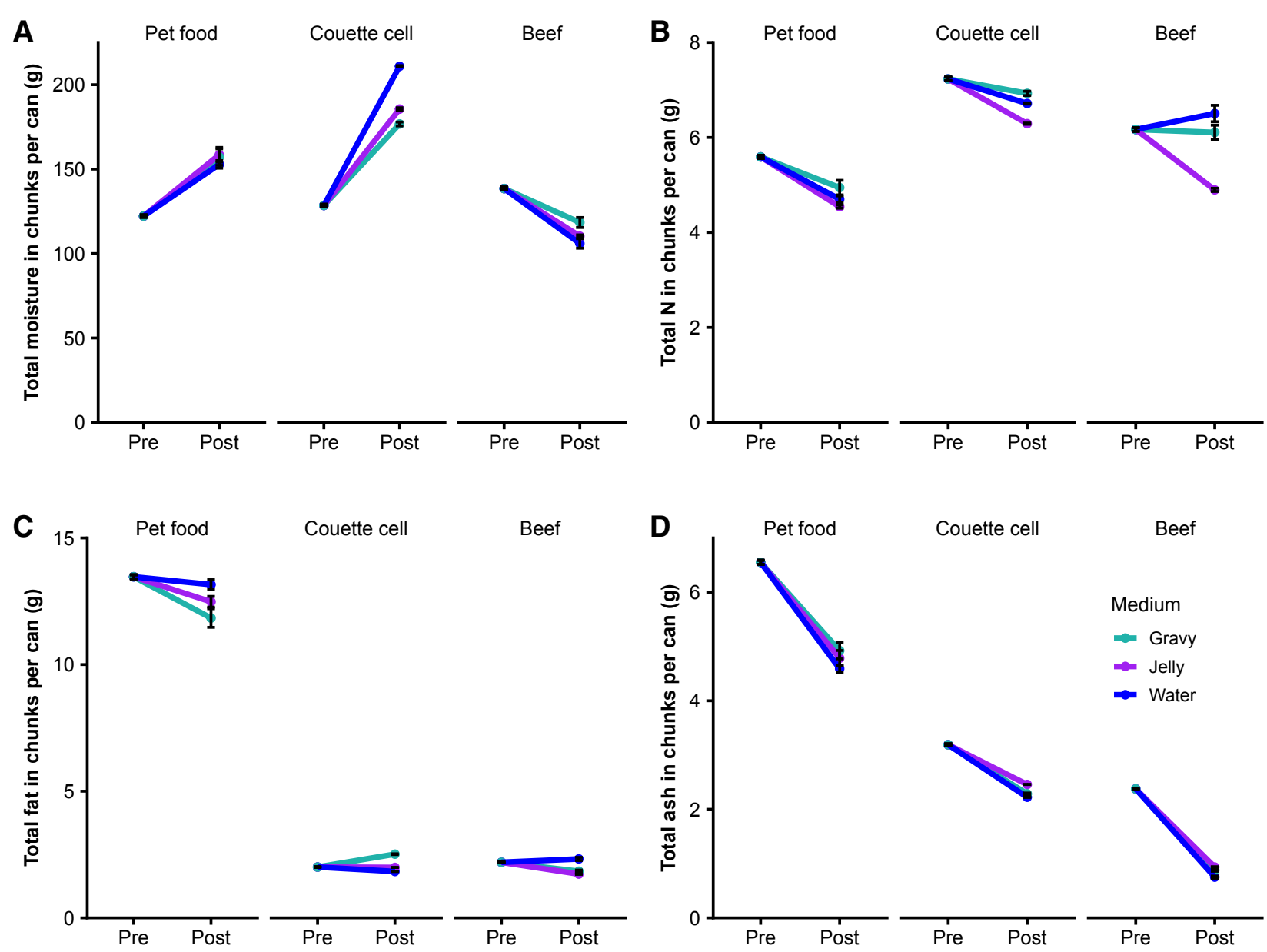

Fig. 2. Moisture, $\mathrm{N}$, fat, and ash content in three kinds of chunks in different media per can pre vs post sterilization (total average amount per can with standard error bars, $\mathrm{n}=2$ ). 

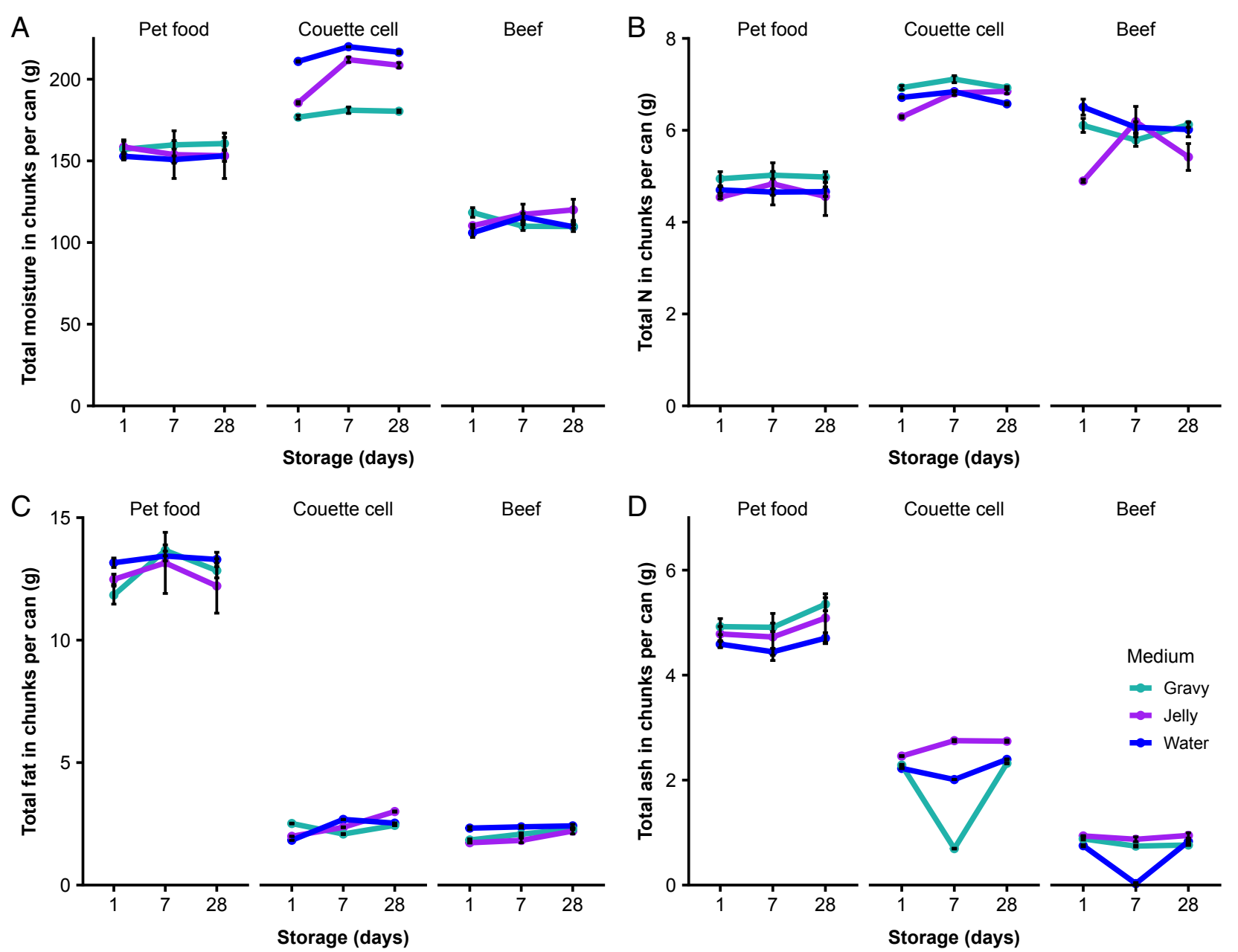

Fig. 3. Moisture, $\mathrm{N}$, fat, and ash content in three kinds of chunks in different media per can during storage (total average amount per can with standard error bars, $\mathrm{n}=2$ ). 

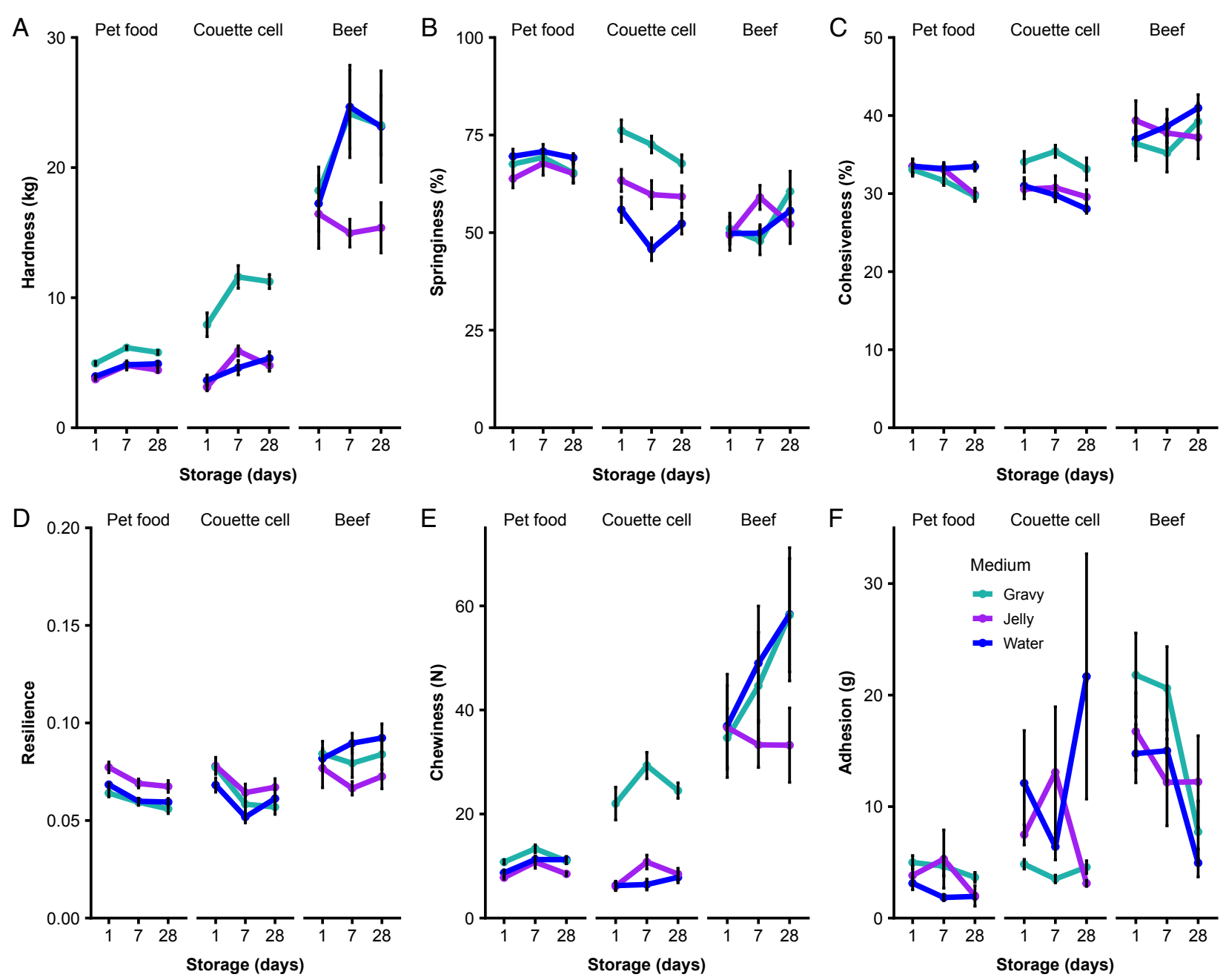

Fig. 4. Effect of storage on textural properties and adhesion of three kinds of chunks in different media (mean values with standard error bars based on $\mathrm{n}=10$ technical replicates). 
involves additional processing, such as sterilization. Those additional processing steps could change the textural properties of the plant-protein based products. To understand the impact of sterilization and storage on pet food quality characteristics texture and stability, a comparative study of chunks of CCMA, a standard pet food and beef in different media (water, gravy, or jelly) was conducted. Sterilization of CCMA chunks resulted in water uptake and swelling and a profound change in textural properties. Remarkably, those changes made CCMA acquire very similar properties compared to pet food chunks, despite clear differences in properties before sterilization. The different responses upon sterilization were in line with differences in water uptake. Water uptake upon sterilization and storage was limited for pet food, water was lost for beef, but CCMA chucks absorbed a substantial amount of water. During storage, the textural properties obtained by sterilization stayed stable as well as the chemical composition. The media in which the chunks were sterilized and stored determined to which extent similarities of pet food and CCMA chunks were displayed.

\subsection{Thermal processing and water holding of proteins}

In general, heat exposure of proteins leads to a decrease in water retention (Zayas, 1997). However, water holding capacity (WHC) is influenced by the material exposed and factors like initial moisture content, temperature, duration of exposure, and pressure (Kinsella, 1979; Hsu et al., 1983; Wang et al., 2019). Toasting (dry heating) soy protein fractions up to $150^{\circ} \mathrm{C}$, for example, increased WHC approximately six fold (Geerts et al., 2018). According to the authors, denaturation and possibly aggregation resulted in decreased protein solubility and explained this increase in WHC. The CCMA is based on $230 \mathrm{~g} / \mathrm{kg}$ SPI and $70 \mathrm{~g} / \mathrm{kg}$ wheat gluten and contained up to $640 \mathrm{~g} / \mathrm{kg}$ more water after sterilization. Gluten can absorb and hold up to twice its weight in water (Day, 2011), which is not influenced by heating. SPI has a high capacity to take up and hold water (Fleming et al., 1974), which capacity may be increased or decreased by thermal processing. Water uptake of SPI dispersed in water at concentrations ranging from $50 \mathrm{to} 150 \mathrm{~g} / \mathrm{kg} \mathrm{w} / \mathrm{w}$ and heated at 80 or $100{ }^{\circ} \mathrm{C}$ for $30 \mathrm{~min}$ was highest for $80 \mathrm{~g} / \mathrm{kg}$ at $100{ }^{\circ} \mathrm{C}$ (Sorgentini et al., 1995). Furthermore, it was suggested that denaturation and aggregation reduced water uptake and retention. However, the percentage soluble and insoluble fractions of SPI determined its final capacity to take up water (Sorgentini et al., 1995).

It is important to note that CCMA has undergone multiple processing steps and has been exposed to heat multiple times. From extraction of SPI and gluten, mixing these ingredients with water and salt followed by creating the CCMA, to subsequent freezing and then sterilization, there were at least three possibilities for denaturation and other conformational changes of the proteins. This may have resulted in reduction of available polar amino acid groups to bind water. However, we observed an increase in WHC. This could have been due to loss of solubility due to denaturation and aggregation, and the high amount of hydrophilic polar amino acids in SPI (Verbeek and van den Berg, 2010; Berghout et al., 2015).

In contrast to CCMA, water loss or syneresis was observed in beef upon thermal treatment, which suggested a decrease in WHC, similarly to what is described in other studies of thermal effect on beef (Bell et al., 2001; Kovácsné Oroszvári et al., 2006). Pet food chunks, also being composed of animal proteins but containing salt and sodium tripolyphosphate, did not show water loss. Different types of animal proteins, like spray dried animal plasma, can increase WHC of pet food (Polo et al., 2005) and therefore lead to a more stable product than if meat alone is thermally treated. As reviewed by Zayas (1997), salt and phosphates can increase WHC of meat and thus be potentially responsible for the differences in response to sterilization. In addition, there is a synergistic effect of water retention when salt and phosphates are used in meat products, as addition of phosphates doubles the effect of salt alone on water binding capacity (Shults et al., 1972). Furthermore, pet food underwent a first heat treatment on the steam tunnel before sterilization. Moisture loss, uptake, and / or denaturation could already occur during this cooking step, resulting in a more stable product during sterilization and storage.

\subsection{Effect of media on moisture absorption and texture}

The similarity in texture of CCMA and pet food was observed when chunks were sterilized in jelly or gravy instead of water. In case of water, the water uptake was so high that CCMA chunks became too soft. Jelly and gravy resulted in lower water uptake. The hydrocolloids in gravy and jelly could have slightly lowered the water activity, leading to a smaller driving force for water migration, or reduced the water mobility. Time affected media and differences in storage behaviour could be observed. Water uptake of chunks in gravy did not change much during storage and seemed complete directly after sterilization (Fig. 3). However, viscosity was lower directly after sterilization than after storage of 28 days (Fig. S2). This indicates that water binding and therefore water uptake was not complete directly after sterilization. For chunks in jelly, moisture content also changed during storage (Fig. 3). Visual inspection reflected this and showed that it takes longer for the jelly than for gravy to reach its final gel state, and therefore gives the chunks more time to absorb water. During storage, CCMA chunks in gravy were harder, springier and less cohesive than chunks in jelly or water.

Table 1

Analysed mean proximate composition (g/kg) of chunks of pet food, couette cell meat analogue (CCMA) and beef before sterilization, $\mathrm{n}=2$.

\begin{tabular}{llll}
\hline Parameter & Pet food & CCMA & Beef \\
\hline Moisture & 672 & 705 & 758 \\
Crude protein & 192 & 248 & 211 \\
Crude fat & 74 & 11 & 12 \\
Crude ash & 36 & 18 & 13 \\
\hline
\end{tabular}


Table 2

Texture and adhesion of three kinds of chunks in different media pre vs post sterilization (mean values with standard errors based on $\mathrm{n}=10$ technical replicates).

\begin{tabular}{|c|c|c|c|c|c|c|c|c|c|c|c|c|}
\hline \multirow[t]{3}{*}{ Parameter } & \multicolumn{4}{|l|}{ Petfood } & \multicolumn{4}{|c|}{ Couette cell } & \multicolumn{4}{|l|}{ Beef } \\
\hline & \multirow{2}{*}{$\begin{array}{l}\text { Pre } \\
\text { a }\end{array}$} & \multicolumn{3}{|l|}{ Post } & \multirow{2}{*}{$\begin{array}{l}\text { Pre } \\
\text { a }\end{array}$} & \multicolumn{3}{|l|}{ Post } & \multirow{2}{*}{$\begin{array}{l}\text { Pre } \\
\text { a }\end{array}$} & \multicolumn{3}{|l|}{ Post } \\
\hline & & water & gravy & jelly & & water & gravy & jelly & & water & gravy & jelly \\
\hline Hardness (kg) & $5.9 \pm 0.3$ & $3.9 \pm 0.1$ & $5.0 \pm 0.1$ & $3.7 \pm 0.1$ & $35.3 \pm 1.7$ & $3.6 \pm 0.4$ & $8.1 \pm 0.9$ & $3.1 \pm 0.3$ & $\begin{array}{l}31.8 \pm \\
3.3\end{array}$ & $\begin{array}{l}17.2 \pm \\
2.1\end{array}$ & $\begin{array}{l}18.3 \pm \\
1.8\end{array}$ & $\begin{array}{l}17.1 \pm \\
2.7\end{array}$ \\
\hline Springiness (\%) & $\begin{array}{l}54.5 \pm \\
1.8\end{array}$ & $\begin{array}{l}68.6 \pm \\
1.8\end{array}$ & $\begin{array}{l}67.6 \pm \\
2.5\end{array}$ & $\begin{array}{l}63.8 \pm \\
2.4\end{array}$ & $99.1 \pm 0.4$ & $\begin{array}{l}55.9 \pm \\
3.2\end{array}$ & $\begin{array}{l}78.2 \pm \\
2.8\end{array}$ & $\begin{array}{l}63.4 \pm \\
2.8\end{array}$ & $\begin{array}{l}26.0 \pm \\
1.2\end{array}$ & $\begin{array}{l}49.8 \pm \\
4.3\end{array}$ & $\begin{array}{l}52.3 \pm \\
4.0\end{array}$ & $\begin{array}{l}50.2 \pm \\
1.5\end{array}$ \\
\hline $\begin{array}{c}\text { Cohesiveness } \\
\text { (\%) }\end{array}$ & $\begin{array}{l}33.1 \pm \\
0.9\end{array}$ & $\begin{array}{l}33.2 \pm \\
0.9\end{array}$ & $\begin{array}{l}33.1 \pm \\
0.8\end{array}$ & $\begin{array}{l}33.5 \pm \\
0.9\end{array}$ & $56.1 \pm 1.1$ & $\begin{array}{l}31.0 \pm \\
1.0\end{array}$ & $\begin{array}{l}34.6 \pm \\
1.3\end{array}$ & $\begin{array}{l}30.6 \pm \\
1.2\end{array}$ & $\begin{array}{l}33.0 \pm \\
1.4\end{array}$ & $\begin{array}{l}37.0 \pm \\
2.7\end{array}$ & $\begin{array}{l}36.3 \pm \\
1.7\end{array}$ & $\begin{array}{l}40.4 \pm \\
2.6\end{array}$ \\
\hline Chewiness (N) & $\begin{array}{l}10.5 \pm \\
0.8\end{array}$ & $8.7 \pm 0.5$ & $\begin{array}{l}10.8 \pm \\
0.4\end{array}$ & $7.8 \pm 0.3$ & $\begin{array}{l}192.1 \pm \\
8.8\end{array}$ & $6.3 \pm 0.8$ & $\begin{array}{l}22.0 \pm \\
3.2\end{array}$ & $6.1 \pm 0.8$ & $\begin{array}{l}28.9 \pm \\
4.2\end{array}$ & $\begin{array}{l}37.0 \pm \\
9.9\end{array}$ & $\begin{array}{l}34.6 \pm \\
5.6\end{array}$ & $\begin{array}{l}36.6 \pm \\
8.1\end{array}$ \\
\hline Resilience & $\begin{array}{l}0.08 \pm \\
0.00\end{array}$ & $\begin{array}{l}0.07 \pm \\
0.00\end{array}$ & $\begin{array}{l}0.06 \pm \\
0.00\end{array}$ & $\begin{array}{l}0.08 \pm \\
0.00\end{array}$ & $\begin{array}{l}0.15 \pm \\
0.00\end{array}$ & $\begin{array}{l}0.07 \pm \\
0.00\end{array}$ & $\begin{array}{l}0.08 \pm \\
0.00\end{array}$ & $\begin{array}{l}0.08 \pm \\
0.00\end{array}$ & $\begin{array}{l}0.15 \pm \\
0.01\end{array}$ & $\begin{array}{l}0.08 \pm \\
0.00\end{array}$ & $\begin{array}{l}0.08 \pm \\
0.00\end{array}$ & $\begin{array}{l}0.08 \pm \\
0.01\end{array}$ \\
\hline Adhesion (g) & $4.0 \pm 0.7$ & $3.1 \pm 0.6$ & $5.0 \pm 0.6$ & $3.8 \pm 0.8$ & $3.2 \pm 0.5$ & $\begin{array}{l}12.1 \pm \\
4.7\end{array}$ & $4.8 \pm 0.4$ & $7.5 \pm 0.9$ & $\begin{array}{l}37.2 \pm \\
4.0\end{array}$ & $\begin{array}{l}14.8 \pm \\
2.6\end{array}$ & $\begin{array}{l}21.8 \pm \\
3.8\end{array}$ & $\begin{array}{l}16.7 \pm \\
3.5\end{array}$ \\
\hline
\end{tabular}

${ }^{\text {a }}$ Not applicable as chunks were not placed in media for the measurement pre sterilization.

Gravy contains salt, which reduces water activity in the medium surrounding the chunks and could account for these results. In conclusion, to manage the equilibrium water content of chunks and the equilibrium water content of hydrocolloids used, media can be utilized to enhance chunk texture.

\subsection{Effect of proximate kinetics on texture}

In this study, the profound changes we observed in moisture content of the chunks were associated with changes in textural properties, but also some changes in $\mathrm{N}$ and fat contents were observed. A negative correlation of moisture content with hardness was already mentioned in classical work of texture scientists (Szczesniak, 1963). Rahman and Al-Farsi (2005) showed that hardness was $171 \mathrm{~N}$ in dates at $170 \mathrm{~g} / \mathrm{kg}$ moisture, whereas this was $3 \mathrm{~N}$ when moisture content was $580 \mathrm{~g} / \mathrm{kg}$. A decrease in cohesiveness, adhesiveness, springiness, and resilience when moisture increased was also observed. In this study however, only the negative relation between moisture and hardness in CCMA chunks and beef seemed evident. Studies reported an effect of fat content ranging from 110 to $610 \mathrm{~g} / \mathrm{kg}$ on textural parameters springiness, hardness, chewiness, gumminess, cohesiveness (Saint-Eve et al., 2009; Sarıçoban et al., 2009; Yilmaz et al., 2012). In the present study, fat content and changes therein after sterilization were minor and probably also caused by variation of fat content in the raw materials. Therefore, the contribution of fat to the observed variations in texture was likely limited. Sterilization resulted in N loss in CCMA and pet food chunks, which both showed decreased hardness after sterilization. The lower N-value suggests protein loss, the results align with measurements in sausages where hardness correlated with protein content (Pietrasik, 1999). Protein content in sausages (Pietrasik, 1999) ranged from 81 to $108 \mathrm{~g} / \mathrm{kg}$ which is comparable to the protein losses of pet food and CCMA, which were between $17-65 \mathrm{~g} / \mathrm{kg}$. However, protein content of pet food and CCMA was about twice as much as the sausages (Table 1). Furthermore, when comparing protein loss of the CCMA, pet food, and beef chunks, this result was not as prominent as the effect of moisture uptake. Moisture uptake of up to $106 \%$ of CCMA chunks after sterilization resulted in CCMA chunks having similar textural properties as pet food. We therefore consider moisture content and WHC as relevant to modify texture parameters after sterilization.

\subsection{Effect of storage}

Textural properties of CCMA product remained in the range of the pet food chunks during storage. This is in contrast to stored canned noodles containing $50 \mathrm{~g} / \mathrm{kg}$ SPI, were textural properties hardness, springiness, cohesiveness, and chewiness further decreased during storage (Yeoh et al., 2014) as a result of continued water uptake during storage. Water uptake in CCMA chunks was very small during storage explaining more stable textural properties. Therefore, the effect of storage seems to be limited. Consequently, properties pre-sterilization and their changes through the sterilization process is, next to WHC of the recipe, the factor that impacts textural properties of the final CCMA in the pet food most. As such, when designing the CCMA to have specific textural properties that should meet certain criteria, one should take into account the impact of sterilization.

\subsection{Eligibility of CCMA as pet food alternative and outlook}

In our study, we used a dog food as a reference product to explore to what extent the CCMA would resemble textural properties of pet foods. Few studies on these properties for pet foods are available in the literature. Hagen-Plantinga et al. (2017) reported firmness of loaf type pet foods from 1.9 to $4.0 \mathrm{~kg}$. Than et al. (2019) compared 42 commercial canned pet foods of the type with chunks and demonstrated hardness values in the range of 9.1-71.2 N. Hardness of CCMA after sterilization measured in this study was in this range for chunks in water and jelly (30.7-46.9 N), whereas chunks in gravy were harder (77.6-113.7 N). In addition, Than et al. (2019) 
reported that strain (force per unit surface area) was the preferred parameter to characterize and compare pet food chunks. Due to the swelling through water uptake, CCMA chunks were larger after sterilization (data not shown), which could have contributed to the change in values for textural parameters after sterilization. Swelling and therefore change in surface area for CCMA chunks in gravy was less than for the other media. This might be reflected in the greater values for hardness and therefore corresponds well with the results of Than et al. (2019). This confirms that, in terms of texture, depending on the medium, CCMA can be used as alternative pet food. The current study focused on a CCMA made from SPI and gluten, whereas a broader range of plant-based ingredients as basis for the CCMA is currently being investigated and will provide more options for pet foods. Furthermore, to ensure the nutritional requirements, the chunks and medium will be formulated such that all essential nutrients are present in sufficient amounts and in a bioavailable form. For example, a premix of vitamins and minerals has to be added. It is of interest to explore if such additions impact the CCMA formation as well as the textural properties of the product after sterilization. These advancements in CCMA design and the investigation of nutritional properties, like amino acid digestibility, are subjects for further research.

\section{Conclusions}

Couette cell meat analogue showed potential to be used as alternative for meat-based chunk in pet-food applications. Especially after sterilization, textural properties were similar and could be tuned by medium composition. Couette cell meat analogue chunks still contained a fibrous appearance upon tearing. Exposing couette cell meat analogue chunks to a typical pet food sterilization process resulted in profound changes in textural properties. It means that fresh couette cell meat analogue may have different properties compared to meat chunks, provided those changes disappear upon further processing.

\section{Funding}

This research is part of the project Plant Meat Matters, which is co-financed by Top Consortium for Knowledge and Innovation Agri \& Food by the Dutch Ministry of Economic Aff ;airs and Climate; the project is registered under contract number TKI-AF-16011.

\section{CRediT authorship contribution statement}

Ariane Maike Wehrmaker: Conceptualization, Methodology, Investigation, Writing - original draft, Funding acquisition. Guido Bosch: Conceptualization, Methodology, Writing - review \& editing, Supervision. Atze Jan van der Goot: Conceptualization, Writing - review \& editing, Supervision, Funding acquisition.

\section{Declaration of Competing Interest}

Ariane Wehrmaker is employee of saturn petcare gmbh.

\section{Acknowledgements}

We thank Klaus Tesch, Udo Sager, everyone from the saturn petcare product development centre especially Peer Sonntag, and Winopal Forschungsbedarf $\mathrm{GmbH}$ for their help with the experiments.

\section{Appendix A. Supplementary data}

Supplementary material related to this article can be found, in the online version, at doi:https://doi.org/10.1016/j.anifeedsci. 2020.114737 .

\section{References}

AOAC International (Association of Official Analytical Chemists International), 2005. Official Methods of Analysis of the AOAC International, 18th ed. AOAC International Gaithersburg, MD, USA.

Bell, J.W., Farkas, B.E., Hale, S.A., Lanier, T.C., 2001. Effect of thermal treatment on moisture transport during steam cooking of skipjack tuna (Katsuwonas pelamis). J. Food Sci. 66, 307-313. https://doi.org/10.1111/j.1365-2621.2001.tb11337.x.

Berghout, J.A.M., Boom, R.M., van der Goot, A.J., 2015. Understanding the differences in gelling properties between lupin protein isolate and soy protein isolate. Food Hydrocoll. 43, 465-472. https://doi.org/10.1016/j.foodhyd.2014.07.003.

Bourne, M.C., 1968. Texture profile of ripening pears. J. Food Sci. 33, 223-226. https://doi.org/10.1111/j.1365-2621.1968.tb01354.x.

Bourne, M.C., 1975. Texture properties and evaluations of fabricated foods. In: Inglett, G.E. (Ed.), Fabricated Foods. Avi. Pub. Co., Westport, Conneticut, USA, pp. 127-158.

Brady, P.L., Hunecke, M.E., 1985. Correlations of sensory and instrumental evaluations of roast beef texture. J. Food Sci. 50, 300-303. https://doi.org/10.1111/ j.1365-2621.1985.tb13386.x.

Chou, D.H., Morr, C.V., 1979. Protein-water interactions and functional properties. J. Am. Oil Chem. Soc. 56, A53-A62. https://doi.org/10.1007/BF02671785.

Day, L., 2011. Wheat gluten: production, properties and application. In: Phillips, G.O., Williams, P.A. (Eds.), Handbook of Food Proteins. Woodhead Publishing, pp. 267-288. https://doi.org/10.1533/9780857093639.267.

De Graaf, L.A., 2000. Denaturation of proteins from a non-food perspective. J. Biotechnol. 79, 299-306. https://doi.org/10.1016/S0168-1656(00)00245-5. 
de Huidobro, F.R., Miguel, E., Blázquez, B., Onega, E., 2005. A comparison between two methods (Warner-bratzler and texture profile analysis) for testing either raw meat or cooked meat. Meat Sci. 69, 527-536. https://doi.org/10.1016/j.meatsci.2004.09.008.

Fleming, S.E., Sosulski, F.W., Kilrara, A., Humbert, E.S., 1974. Viscosity and water absorption characteristics of slurries of sunflower and soybean flours, concentrates and isolates. J. Food Sci. 39, 188-192. https://doi.org/10.1111/j.1365-2621.1974.tb01019.x.

Fox, R., Gee, N.R., 2017. Great expectations: changing social, spatial and emotional understandings of the companion animal-human relationship. Soc. Cult. Geogr. 20, 43-63. https://doi.org/10.1080/14649365.2017.1347954.

Geerts, M.E.J., Dekkers, B.L., van der Padt, A., van der Goot, A.J., 2018. Aqueous fractionation processes of soy protein for fibrous structure formation. Innov. Food Sci. Emerg. Technol. 45, 313-319. https://doi.org/10.1016/j.ifset.2017.12.002.

Hagen-Plantinga, E.A., Orlanes, D.F., Bosch, G., Hendriks, W.H., van der Poel, A.F.B., 2017. Retorting conditions affect palatability and physical characteristics of canned cat food. J. Nutr. Sci. 6, e23. https://doi.org/10.1017/jns.2017.17.

Hendriks, W.H., Bosch, G., 2018. Aspects of comparative animal nutrition and the evaluation of pet foods. In: Moughan, P.J., Hendriks, W.H. (Eds.), Feed Evaluation Science. Wageningen Academic Publishers, Wageningen, the Netherlands, pp. 491-524. https://doi.org/10.3920/978-90-8686-854-4.

Hoek, A.C., van Boekel, M.A.J.S., Voordouw, J., Luning, P.A., 2011. Identification of new food alternatives: how do consumers categorize meat and meat substitutes? Food Qual. Prefer. 22, 371-383. https://doi.org/10.1016/j.foodqual.2011.01.008.

Hsu, K.H., Kim, C.J., Wilson, L.A., 1983. Factors affecting water uptake of soybeans during soaking. Cereal Chem. 60, $208-211$.

Kinsella, J.E., 1979. Functional properties of soy proteins. J. Am. Oil Chem. Soc. 56, 242-258. https://doi.org/10.1007/BF02671468.

Kovácsné Oroszvári, B., Bayod, E., Sjöholm, I., Tornberg, E., 2006. The mechanisms controlling heat and mass transfer on frying of beefburgers. III. Mass transfer evolution during frying. J. Food Eng. 76, 169-178. https://doi.org/10.1016/j.jfoodeng.2005.05.018.

Krintiras, G.A., Gobel, J., Bouwman, W.G., Jan van der Goot, A., Stefanidis, G.D., 2014. On characterization of anisotropic plant protein structures. Food Funct. 5, 3233-3240. https://doi.org/10.1039/c4fo00537f.

Krintiras, G.A., Gadea Diaz, J., van der Goot, A.J., Stankiewicz, A.I., Stefanidis, G.D., 2016. On the use of the couette cell technology for large scale production of textured soy-based meat replacers. J. Food Eng. 169, 205-213. https://doi.org/10.1016/j.jfoodeng.2015.08.021.

Okin, G.S., 2017. Environmental impacts of food consumption by dogs and cats. PLoS One 12, e0181301. https://doi.org/10.1371/journal.pone.0181301.

Pietrasik, Z., 1999. Effect of content of protein, fat and modified starch on binding textural characteristics, and colour of comminuted scalded sausages. Meat Sci. 51, 17-25. https://doi.org/10.1016/S0309-1740(98)00068-0.

Polo, J., Rodríguez, C., Saborido, N., Ródenas, J., 2005. Functional properties of spray-dried animal plasma in canned petfood. Anim. Feed Sci. Technol. 122, 331-343. https://doi.org/10.1016/j.anifeedsci.2005.03.002.

Rahman, M.S., Al-Farsi, S.A., 2005. Instrumental texture profile analysis (TPA) of date flesh as a function of moisture content. J. Food Eng. 66, 505-511. https://doi. org/10.1016/j.jfoodeng.2004.04.022.

Saint-Eve, A., Lauverjat, C., Magnan, C., Deleris, I., Souchon, I., 2009. Reducing salt and fat content: impact of composition, texture and cognitive interactions on the perception of flavoured model cheeses. Food Chem. 116, 167-175. https://doi.org/10.1016/j.foodchem.2009.02.027.

Sarıçoban, C., Yılmaz, M.T., Karakaya, M., 2009. Response surface methodology study on the optimisation of effects of fat, wheat bran and salt on chemical, textural and sensory properties of patties. Meat Sci. 83, 610-619. https://doi.org/10.1016/j.meatsci.2009.07.010.

Shults, G.W., Russell, D.R., Wierbicki, E., 1972. Effect of condensed phosphates on pH, swelling and water holding capacity of beef. J. Food Sci. 37, 860-864. https:// doi.org/10.1111/j.1365-2621.1972.tb03688.x.

Sorgentini, D.A., Wagner, J.R., Anon, M.C., 1995. Effects of thermal treatment of soy protein isolate on the characteristics and structure - function relationship of soluble and insoluble fractions. J. Agric. Food Chem. 43, 2471-2479. https://doi.org/10.1021/jf00057a029.

Stephens, N., Di Silvio, L., Dunsford, I., Ellis, M., Glencross, A., Sexton, A., 2018. Bringing cultured meat to market: technical, socio-political, and regulatory challenges in cellular agriculture. Trends Food Sci. Technol. 78, 155-166. https://doi.org/10.1016/j.tifs.2018.04.010.

Su, B.T., Martens, P., Enders-Slegers, M.J., 2018. A neglected predictor of environmental damage: the ecological paw print and carbon emissions of food consumption by companion dogs and cats in China. J. Clean. Prod. 194, 1-11. https://doi.org/10.1016/j.jclepro.2018.05.113.

Swanson, K.S., Carter, R.A., Yount, T.P., Aretz, J., Buff, P.R., 2013. Nutritional sustainability of pet foods. Adv. Nutr. 4, 141-150. https://doi.org/10.3945/ an.112.003335.

Sworn, G., 2009. Xanthan gum, food stabilisers. In: Imeson, A. (Ed.), Thickeners and Gelling Agents. Wiley -Blackwell, Chichester, United Kingdom, pp. 325-342. Szczesniak, A.S., 1963. Classification of textural characteristicsa. J. Food Sci. 28, 385-389. https://doi.org/10.1111/j.1365-2621.1963.tb00215.x.

Than, T.T.T., Wehrmaker, A.M., van Der Goot, A.J., Bosch, G., 2019. Texture Profiling of Wet Foods for Dogs and Cats. Congress of the ESVCN, Turin, Italy, p. 214.

Toldrá, F., Mora, L., Reig, M., 2016. New insights into meat by-product utilization. Meat Sci. 120, 54-59. https://doi.org/10.1016/j.meatsci.2016.04.021.

Verbeek, C.J.R., van den Berg, L.E., 2010. Extrusion processing and properties of protein-based thermoplastics. Macromol. Mater. Eng. 295, 10-21. https://doi.org/ 10.1002/mame.200900167.

Wang, B., Liu, F., Luo, S., Li, P., Mu, D., Zhao, Y., Zhong, X., Jiang, S., Zheng, Z., 2019. Effects of high hydrostatic pressure on the properties of heat-induced wheat gluten gels. Food Bioproc. Tech. 12, 220-227. https://doi.org/10.1007/s11947-018-2205-3.

Yeoh, S.-Y., Alkarkhi, A.F.M., Easa, A.M., 2014. Effect of cross-linking agents on physicochemical, textural properties and microstructure of canned soy protein isolateyellow alkaline noodles prepared by retort processing. J. Food Process. Preserv. 38, 1187-1197. https://doi.org/10.1111/jfpp.12079.

Yilmaz, M.T., Karaman, S., Dogan, M., Yetim, H., Kayacier, A., 2012. Characterization of o/w model system meat emulsions using shear creep and creep recovery tests based on mechanical simulation models and their correlation with texture profile analysis (TPA) parameters. J. Food Eng. 108, 327-336. https://doi.org/ 10.1016/j.jfoodeng.2011.08.005.

Zayas, J.F., 1997. Water Holding Capacity of Proteins, Functionality of Proteins in Food. Springer Berlin Heidelberg, Berlin, Heidelberg, Germany, pp. 76-133. https://doi.org/10.1007/978-3-642-59116-7_3. 